\title{
Algeria and women in two 1960s film adaptations of the Carmen narrative Phil Powrie, University of Surrey
}

\begin{abstract}
This paper considers two very different 1960s adaptations of the Carmen narrative --1-2-3-4 ou Les Collants noirs (1962) and Carmen 63 (1963)-- to show how they articulate common social and political concerns. The first of these, common to many of the Carmen films, is the fear of women's increasing independence, linked to the development of the post-war consumer culture. The second is a converging concern with the Algerian War, hidden deep in the films, but emerging symptomatically through, amongst other features, the choice of star in one of the films (Jacques Charrier), the fear of the 'foreign', and the dilution of Carmen as a nineteenth-century French heritage icon.
\end{abstract}

\section{Keywords}

Carmen

Condition of women

Algerian War

Les Collants noirs

Carmen 63

Brigitte Bardot

Zizi Jeanmaire

Jacques Charrier 
It is a commonplace of film history that French films dealing with the Algerian War during or immediately after the War itself are few, and those that do exist deal with it allusively: Le Petit Soldat (Jean-Luc Godard, 1960, but banned until 1963), Cléo de 5 à 7 (Agnès Varda, 1962), Adieu Philippine (Jacques Rozier, 1963), La Belle Vie (Robert Enrico, 1963), Muriel (Alain Resnais, 1963), Les Parapluies de Cherbourg (Jacques Demy, 1964). It was only La Bataille d'Alger (Gillo Pontecorvo, 1965) which dealt with it directly in the 1960s (see Dine, 1994: 215-32). My contention will be that more films than we might think are articulated around 'Algeria'. I shall analyse two adaptations of the Carmen narrative to explore this contention. The Carmen narrative occurs at times of significant social and political change (see Powrie et al., 2007). In the case of these two 1960s films, the figure of Carmen, the passionately desiring woman who longs for freedom -'Libre elle est née, et libre elle mourra!' she sings in the opera's final duet before don José kills her-represents a number of overlapping and feared urges for freedom: social freedom for women in the home, political freedom for women in France, and political freedom for the colonized abroad.

The Carmen narrative is one of the most frequently adapted to the screen, with some 80 films since 1895, of which 17, if we include co-productions, are French. Two of these 17 were released in the early 1960s. They are 1-2-3-4 ou Les Collants noirs (Terence Young, 1962), a film version of Roland Petit's scandalous 1949 ballet; and Carmen di Trastavere (Carmine Gallone, 1963), a Franco-Italian co-production, known in France under the title Carmen 63. These two films have been over-shadowed by the crop of adaptations which occurred in the mid-1980s, to which considerable academic attention has been devoted: Peter Brook's three film versions of his theatrical production (1983); Jean-Luc Godard's Prénom: Carmen (1983); Francesco Rosi's 'realist' version of the opera (1984); and to these we can add the Spanish flamenco adaptation by Carlos Saura (1984), as well as the less well-known French soft-porn Carmen by Albert Lopez (1984) (see Davies and Powrie, 2006). 
There is an African connection which motivates the search for a hidden Algeria in the Carmen narratives of the 1960s. Mérimée's novella of 1845 refers on many occasions to Egypt (the word at the origin of the appellation 'gypsy', because gypsies were said to have originated there), and Nietzsche observed that the opera Bizet had made of the novella had an African sensibility (quoted in McClary, 1992: 118). The Algerian connection is linked, I would like to argue, to another major issue for post-war French society, and a commonplace of the Carmen adaptations more generally: the gradual emancipation of women, in this case in and through the newly-emerging consumer society.

\section{1-2-3-4 ou Les Collants noirs}

1-2-3-4 ou Les Collants noirs is a collection of four short ballets by Roland Petit, of which 'Carmen' is the last. Petit's ballet was not the first time the story had been used for ballet. The Russian choreographer Marius Petipa wrote Carmen et son Toréro (1845), based on Mérimée's novella, well before Bizet's opera. Ballet versions of Carmen occurred regularly in London's Alhambra Ballet Theatre, with or without Bizet's music (1897, 1903, and 1912). Petit's ballet, which did use Bizet's score, although compressing the opera considerably, premiered at Prince's Theatre in London on 21 February 1949. Petit had joined the Paris Opera company in 1939 as a dancer. Some ten years later, in 1948, he founded 'Les Ballets de Paris de Roland Petit', and wrote Carmen for his ballerina wife Renée ('Zizi') Jeanmaire. It was a succès à scandale, occasioned by a number of daring breaks with tradition. Jeanmaire's hair was cropped short, and she and the other women of the company, well before Madonna's 'material girl' of the 1980s, were dressed in bodices (designed by Yves Saint-Laurent), both elements of style which were to be copied by others subsequently. As Christopher Bowen comments: 
At the time of its premiere in 1949, Carmen was the last word in chic; today it seems as much an emblem of its time as the New Look. And just like Dior's signature couture collection, Carmen came as a shock to post-war society. Audiences in those days expected ballerinas to appear as fairies or enchanted maidens; what they got was Jeanmaire's tough, gamine anti-heroine, a Carmen who embraces her fate with an existential largesse. All of the characters in Petit's condensed dance version (...) are spiky, modern malcontents, and Petit reflects this in the movement vocabulary. This is a ballet almost entirely made up of grand gestures, and there is a belligerence to the posturing. (Bowen, 2002)

But the main reason for the scandal was the eroticism of the choreography. A recent appraisal of Jeanmaire's performance speaks of 'the slutty tilt of her shoulders and hips, the sullen, demanding stab of her pointes against the floor and the wantonly explicit demeanour of the love scenes between her and Petit' (Mackrell, 2002: 5); as Linda Hutcheon says, 'the lovers' choreographed interactions are decidedly risqué for the times' (Hutcheon, 2006: 164). The pas de deux in Don José's bedroom culminates in a striking and highly erotic pose as Petit lies on the floor with Jeanmaire lying on her front and arching upwards from his crotch, literalising the penis suggested by her nickname, Zizi (see Figure 1); Life in 1949 called the ballet 'an erotic romp' (Life, 1949: 94), and the caption for a still of this shot on the same page reads: 'emotional peak at finish of long love scene draws loudest applause of the evening'. 


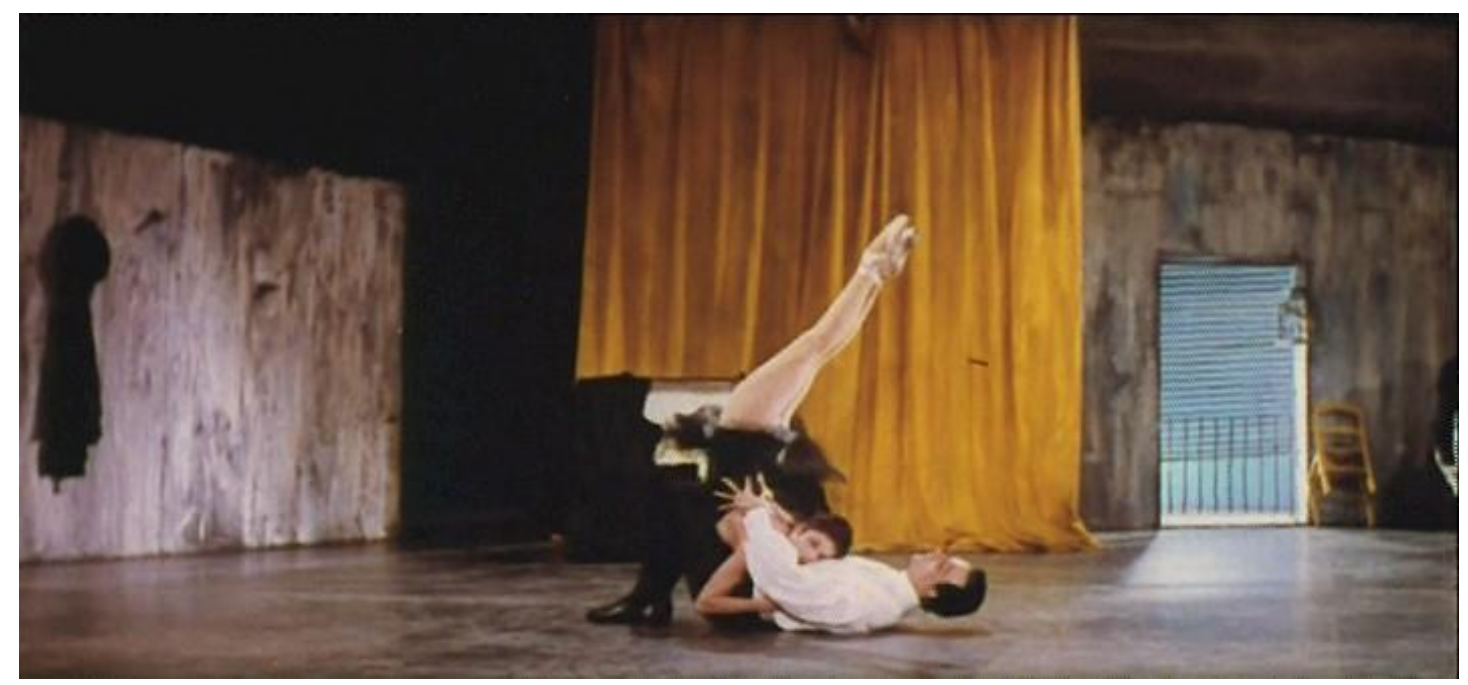

Figure 1. The 'emotional peak' (Courtesy of Kino Video).

The ballet was filmed some ten years later, and the film of which it formed part opened the twenty-first Venice Film Festival on 24 August 1960 under the title Un, deux, trois, quatre!, the allusion being to the four pieces of which 'Carmen' was one; it went on general release in France on 13 June 1962 under the title 1-2-3-4 ou Les Collants noirs (Black Tights in the UK and the USA). ${ }^{\mathrm{i}}$ The theatrical trailer described Jeanmaire as 'that curvaceous sorceress (...), one of the world's most provocative performers', and described the 'Carmen' section as 'the tale of a fiery temptress who destroyed her love and herself through passion'. The film was directed by the British director Terence Young, prior to his James Bond films; ${ }^{\text {ii }}$ and the film and each section of it is introduced by Maurice Chevalier as a kind of genial stereotype of Frenchness. His commentary (in his trademark heavily-accented English) frames the Carmen narrative in much the same way that Mérimée's narrator does in the novella; and, arguably, it has the same effect of containing the scandalously erotic nature of what we see. A modern, spiky (to use Christopher Bowen's term quoted above) eroticism is neutralised by an emphasis on 'timelessness', and somewhat incoherent semantics: 
Come with me now to Sevillia. In what year? 1830, or whatever you like. The story? It is the story of a man, Don José, who is destroyed by passion. And of a woman, Carmen, who destroys through passion. Carmen is timeless, in a Spain given over to love, of love, or death, of death.

Given the fascination of the French for technology in the post-war period, it is not surprising that one of the main talking points in 1960 was that this was the first film in $70 \mathrm{~mm}$ Super Technirama. It is tempting to see this fascination as a displacement for scandalous eroticism; however, what was scandalous in 1949 might have seemed much less so in 1960, as is borne out by reactions to the film more generally. Reactions in France were either respectful, or hostile. Reviewers pointed out that the film would preserve a high-point of French culture, 'une des époques les plus brilliants de la danse' (Paris-Presse, 1962), ${ }^{\text {iii }}$ the effervescence created by Petit in the late 1940s, for future generations; it would allow such art-forms to be more widely disseminated, into the provinces, for example, suggesting the democratisation of a high-art form. What made this possible in part was the apparently 'neutral' use of the camera, which occasioned considerable and much weightier criticism.

French reviewers complained that the camera had been merely used to record another medium. They contrasted the film unfavourably with American musicals such as the recent West Side Story (Jerome Robbins/Robert Wise, 1961), or Gene Kelly's collaborations with Stanley Donen or Vincente Minnelli, aptly contrasted in their view no doubt because several of those films starred Cyd Charisse who performs one of the four ballets in Les Collants noirs, 'Deuil en vingt-quatre heures'. 'T The implication was that Les Collants noirs was not really a film: 
Terence Young (...) n'a apporté à l'entreprise aucune invention cinématographique. Tout ce qu'il semble savoir faire c'est ouvrir une séquence sur un plan à la grue. Le reste est affaire de montage. Au contraire de ces merveilleux ballets américains filmés pas Gene Kelly, Stanley Donen et Minnelli qui savant utiliser l'espace, ceux-ci semblent étriqués, maintenus de force dans les limites d'un plateau de cinéma qui rappelle la scène du théâtre. Les couleurs ne sont pas toujours heureuses. (Télérama, 1962)

These views need to be contrasted with those of non-French reviewers, however. Young was praised by a Belgian reviewer for recording the performance, but his role as director, pointed out the reviewer, quite clearly did not stop there: 'un rôle apparemment peu spectaculaire mais qui, au fil des minutes, se précise non seulement par le cadrage des remarquables décors de Georges Wakhévitch et l'utilisation de l'écran large mais aussi par l'emploi de la couleur et dans le découpage' (Soir de Bruxelles, 1963). Similarly, a UK reviewer also praised Young's direction, which 'concentrates on the dance while relieving the enclosed atmosphere of conventional filmed ballet with head-on shots and skilful use of studio cranes. (...) Young's touch is nicely stylized, as in the death scene in Carmen' (Monthly Film Bulletin, 1961: 126). The disparity in the views between French and nonFrench reviewers suggests fault lines which need to be teased out. I shall do so once I have considered the other 1960s version of Carmen, a Franco-Italian co-production.

\section{Carmen 63}

Released in Paris on 14 August 1963, Carmen di Trastavere was directed in black and white by the veteran Italian director Carmine Gallone. It starred Jacques Charrier and the Italian star Giovanna Ralli, who had made a name for herself playing tough women. The film was 
retitled Carmen 63 in France to signal its contemporary feel. In this version, Antonio, as Don José is renamed, is a police-officer in Rome, who falls for Carmen, a singer and the wife of a drug-dealer, when he sees her sing in a café; she eventually falls for Luca, a would-be motorbike champion (the Lucas of Mérimée's novella, and the Escamillo of the opera). The roles and some details of décor apart, the plot stays close to Mérimée: Carmen fights with the girlfriend of an American in the opening café scene. He is not imprisoned, but does observe her singing and dancing at a soirée, where, interestingly, she does the twist with a black American. Antonio joins the gang led by Vincenzo (veteran thriller actor, Lino Ventura), Carmen's husband; Vincenzo is not killed by Antonio, despite considerable friction between them, but is shot by the American the gang are trying to rob. Carmen immediately leaves him and meets Luca in a café, before watching him die as he races, subsequent to which Antonio kills her.

Consternation at the transposition to modern times surfaces in many of the reviews, and was no doubt part of the reason why the film was poorly received, as it was unfavourably contrasted with Otto Preminger's Carmen Jones (1954), one of the first Carmen films to be set in modern times, and unviewable in France due to copyright restrictions invoked by the Bizet estate. Carmen 63 was said to be 'insignifiant' (Intérim, 1963), full of 'poncifs' with characters ‘tirés de bande dessinée' (Lachize, 1963); more nastily it was 'plus voisine de zéro que de 63' (France-Soir, 1963), with Télérama's reviewer being particularly vituperative: 'la platitude le dispute à la sottise, la médiocrité à la convention. Seul l'ennui triomphe' (Trémois, 1963).

One of the reasons for the unpleasantness is the fact that it was a co-production. One reviewer ends his piece with an ironic comment which makes clear that it is the fact that the film is a co-production which matters: 'C'est sans doute une de ces réussites du cinema franco-italien qui s'est mis en tête de "réparer" les excès de "la nouvelle vague"!' (Chapier, 
1963). To understand the antipathy towards co-productions by industry professionals, it is worth explaining briefly the context of French cinema in the 1950s. With the advent of television and the leisure society, spectator figures had plummeted during the 1950s, even if the number of films had remained more or less the same (about 115 per annum) at a time when the cost of making films was rising. This was in some part thanks to co-productions.

The French producer André Paulvé had been co-producing with the Italians since 1939; Christian-Jaque had made a version of Carmen in the 1940s (made in 1942 and released in 1945) in Italy with La Scalera, one of several Italian companies involved in co-productions. France and Italy had signed an agreement for co-productions as early as February 1949, and in the decade which followed there had been some 382 co-productions, of which 325 were with Italian producers (see Crisp, 1993: 79-82). In 1960, there were 199 'French' films, but only 79 of them were $100 \%$ French, with Italy accounting for some $80 \%$ of the coproductions (Frodon, 1995: 138; for more details see Gili and Tassone, 1995). Although coproductions may well have kept the French industry healthy, they were resented. In the case of Carmen 63, this was all the more so because it was a mainly Italian film doing a disservice by its vulgarity to a French national treasure: 'La nouvelle de Mérimée ne mérite peut-être pas cette indignation' (Chapier, 1963).

In the light of the concerns about co-productions, it is no surprise that the stars were differently treated by French reviewers, in ways which can only seem xenophobic today (see Figure 2). Ralli was 'sauvée par sa plastique' (Lachize, 1963), while comments on Charrier, 'notre compatriote' (Intérim, 1963), revolve around the issue that he is a foreign body. He is ill at ease, 'emprunté sous l'uniforme, assez maladroit' (Intérim, 1963); '(il) se promène dans cette histoire avec le masque d'ennui de celui qui se demande ce qu'il fait là' (Lachize, 1963); and 'seul le visage de Jacques Charrier sauve le film d'une indéniable vulgarité' (Chapier, 1963). Figure 2 is representative of the misalignment between the two stars: 
Charrier comes across as stilted, and spends much of the film frowning; while Ralli is stereotypically Italian, with strong gestures, wide-open eyes and pouting lips.

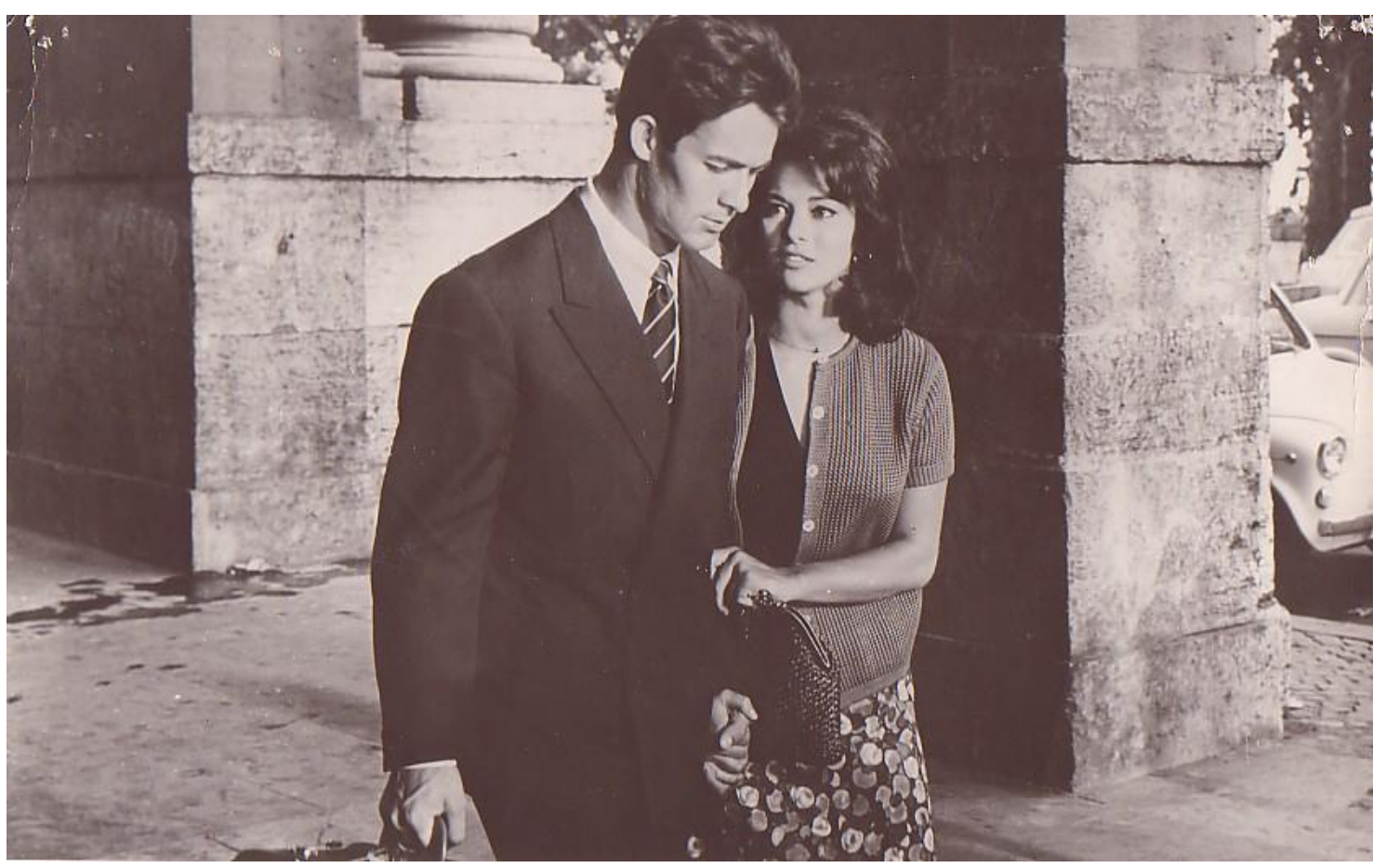

Figure 2. Jacques Charrier and Giovanna Ralli in Carmen 63 (Publicity still, photographer uncredited)

For a French audience, Ralli would have been of less interest, indeed, than Charrier, and not just because of his Frenchness, but because he was the recently divorced husband of Brigitte Bardot. They had married in 1959 when Bardot had become pregnant by him. Their marriage was short-lived, Charrier being jealous of her career and insisting on wielding the authority which the law gave him. He tried to prevent her from acting in Henri_Georges Clouzot's La Vérité (1960) when he knew she was pregnant, saying to her agent, according to Bardot's memoirs: 'Je suis son mari ! C'est moi qui dorénavant déciderai de ce que ma femme tournera ou ne tournera pas! Or je n'ai plus envie qu'elle tourne, il faudra qu'à l'avenir elle s'occupe de son bébé' (Bardot, 1996: 321). Their relationship was stormy; he 
frequently lost his temper, and beat her on at least one occasion during her pregnancy, according to Bardot (Bardot, 1996: 334). Both she (twice) and he (once) tried to commit suicide before their son's birth in January 1960, and she attempted suicide a third time in the autumn of 1960. ${ }^{\mathrm{v}}$ They were estranged in 1961, as Bardot began to see the actor Sami Frey, and they divorced in January 1963, seven months before the release of Carmen 63, all of these events being covered in considerable detail by the press. Seeing Charrier in the story of a torrid love affair gone wrong so soon afterwards could hardly not strike a chord with French audiences. It is likely that many would have seen Ralli as a palimpsest of Bardot (there are some physical similarities, for example in the pout of the lips, as can be seen in Figure 2), not least when, after acting inexpressively and woodenly throughout the film—indeed, suggesting that he would rather have been elsewhere than in this story which must have seemed rather like his own domestic story-Antonio/Charrier abruptly, and unexpectedly, erupts at the end of the film to kill Carmen, who goads him, saying 'tue-moi, si t'en as le courage'. We therefore need to consider what Bardot might have meant for a contemporary audience, and how this might have affected their view of Carmen 63.

Bardot's image in her films, as well as what they learnt of her private life, had affected French youth's perception of conventional morality. Bardot appeared to be sexually emancipated and amoral, rather like the 'spiky malcontent' Jeanmaire in Collants noirs:

A main source of Brigitte Bardot's appeal was that she was like a female James Dean, with her almost masculine aura of independence and rebelliousness. At the same time, she exuded sex-appeal even when wearing jeans. She became a symbol, almost a product, of the collective imagination of adolescent females, who yearned for lives of action and intense experience rather than those led by their mothers. (Laubier, 1990: 31) 
Things had certainly changed for women more generally since the 1920s. The advent of rapid urbanisation and the consumer and leisure society meant that women had more time, thanks to household appliances, and were more mobile thanks to the rapid spread of car ownership: 'ten times more women had driving licences in 1959 than in 1949' (Laubier, 1990: 28). Women were also more financially independent. In 1952 they were able to open a savings account—but not a bank account—without their husband's agreement; they were only to become fully independent of their husbands in 1965, and contraception was made legal only in 1967. That financial independence, coupled with the credit boom of the 1950s in which women were the principal consumers, did not just emancipate women, but also gave women the possibility of fulfilling desires, even if those desires were materialist. Weiner cites the women's magazine Elle from 1956: 'Les femmes osent à présent désirer quelque chose (...) le désir est devenu besoin et (...) le besoin deviendra peu à peu réalité' (cited in Weiner 1995: 124); the 'desire' in question relates not to political issues, but to the 'revolution' created by household appliances. Whichever way one looks at it, women were gradually freeing themselves from the tutelage of their husbands, and were more likely to cater to their own desires.

\section{Freedom at home and abroad}

Charrier's behaviour towards Bardot was legal, therefore, but quickly becoming out of date.

Carmen 63 would have signaled the new morality: the natural, the sensuous, the rebellious. And the last two were undoubtedly also signaled in Zizi Jeanmaire's 'aggressive' performance in her husband's ballet. Women's magazines both intimated freedom for women through consumerism, while at the same time constraining them through domesticity (Weiner 2000: 153-56). Social and political conditions for women operated a similar double standard 
by giving them the vote and increasing financial independence through the credit culture, but keeping them under the tutelage of their husbands. In much the same way, these two films put aggressively independent women on display, foregrounding their desires, but punishing them for those desires. Not only do the films' narratives operate in this way, but so too do other elements. What was revolutionary in formal terms in 1949 is obviously not so revolutionary ten years later, especially not when the narrative is framed by Chevalier; similarly, Bardot is present liminally as threat, but is neutralised by Carmen 63's use of an Italian actress.

Punishment of the desiring woman, the standard function of the Carmen narrative, is one major reason, I would contend, for the reappearance of the Carmen story in film in the 1960s. The Carmen narrative resurfaces because it functions in very specific circumstances to enable the representation of women's desires while also containing them. The message, then, is: 'you can enjoy the new freedoms changing circumstances are offering you. But don't go too far; remember that your husband is still your master'. That message of threatened mastery leads us to the second and equally determining historical circumstance for understanding these two films, which had very little to do with the domestic sphere: the Algerian War.

The Algerian War had started in 1954, leading to De Gaulle's return to politics and a new constitution in 1958. Bardot's memoirs recall that one of the many pressures on her was the threat of national service for Charrier, and then subsequently Frey, both of whom went to considerable lengths to get themselves discharged. Indeed, cinema audiences were well aware of this, and generally disapproved of Charrier for that reason. A recent biography of Bardot quotes a report in Jours de France at the time that Babette s'en va-t-en guerre (ChristianJaque, 1959), starring Bardot and Charrier, was released : 'A Paris, sa réforme temporaire a fait l'effet d'une bombe dans la rue. Les gens s'insurgent, crient au scandale. En province, dans les cinémas où l'on donne Babette s'en va-t-en guerre les spectateurs sifflent dès que Charrier apparaît en fringant officier' (Choulant, 2009: 101). The war surfaces occasionally 
in the text of her memoirs during this period, not least when she was threatened with extortion by the clandestine far-right organisation, the OAS, in November 1961. She subsequently went public with the extortion letter, the first French person to do so, despite the fact that many had been threatened in this period (Bardot, 1996: 421). The war, I would contend, is even more of a subtext for audiences of these two films than the new morality which they suggest, and which audiences would have linked to Bardot. It is this, I would suggest, that occasions the aggressive reactions of French critics to Les Collants noirs in particular, reactions that are all the more striking given the favourable reactions of critics in many other countries; but it also explains the hostility to Carmen 63. French reviewers were reacting to the films' 'foreignness': an English director and an Italian director vulgarising (as Chapier's review cited above makes clear) and displacing an essentially French heritage icon.

Displacement is very clear in Carmen 63, on two levels. First, there is Charrier and his association with the War. Relocating him in Italy, where he appears out of place, as commented on by reviewers, suggests a very literal displacement, and recalls the fate of so many young men sent to Algeria unwillingly. There is a second displacement of a more concrete kind in the film. In the closing scenes, the action takes place in wasteland; Carmen's motorbiking lover is killed in an accident, and Antonio finally kills her. This wasteland is some way from the city -high-rise flats can be seen in the distance-and is a desert-like space, with old ruins, recalling the Algerian maquis. I am not suggesting that this was an intentional reference to the Algerian War; I am, however, suggesting that the combination of décor and what audiences would have known about Charrier, might well have signaled such connections.

Beneath the surface, then, the films articulate deep-rooted fears. I have signaled two strands of interpretation for these films: the changing role of women, and the Algerian crisis. I contend that the two are intimately connected. Given that the previous French adaptation of 
Carmen dates back to the early 1940s, and that the next adaptations were not until the mid1980s, it is legitimate to ask the question: why do these two films appear at the moment of the Algerian crisis? The Carmen story is about the punishment of a woman for wanting to be free. Culturally and politically, then, these two films manage subtextually to equate the freedom of women and the freedom of the Algerian liberation fighters, and to contain both of them by their narrative structure ${ }^{\mathrm{vi}}$ meanwhile, the males take the back stage so that the women can, once again, be foregrounded and punished for taking centre stage. The dangerous new morality so vividly expressed by Bardot underneath the palimpsest of Giovanna Ralli, and the politically unacceptable urge for freedom by Algerians, are fused and confused in a paranoid nexus. That nexus combines domestic relationships (Bardot/Charrier, Jeanmaire/Petit), and national relationships (France/UK for the ballet film, France/Italy for Carmen 63). These two sets of relationships evoke while at the same time they hide an unconscious referent: the relationship between France and Algeria.

The hidden violence I have tried to foreground in these films is best encapsulated by Jeanmaire's dangerously phallic woman, who emerges as an obscene protuberance from Petit's prostrate, tight-clad, demasculinised military male, and his grimly unchanging ironic smile. That smile, retrospectively, seems more like the rictus signaling the humiliation of the French male in social terms and of the French state in political terms. The 'black tights' of the title mourn the passing of the military male, and his enforced capitulation to the feminised spectacle of the new consumer culture.

\section{Notes}

\footnotetext{
${ }^{\text {i }}$ A new stand-alone version of Petit's Carmen was filmed in 1980 for the video market, starring Mikhail Baryshnikov and Jeanmaire.
} 
${ }^{\text {ii }}$ He directed Dr No (1962), From Russia with Love (1963) and Thunderball (1965). Prior to Collants noirs, he was a jobbing director of British war or adventure films, such as The Red Beret (1953), and Safari (1956).

iii This article, and subsequent unpaginated references, are taken from the collection of online and usually unpaginated press clippings at the Bibliothèque du Film in Paris.

iv On the Town (Stanley Donen/Gene Kelly, 1949); The Pirate (Vincente Minnelli, 1948); An American in Paris (Minnelli 1951); Singin' in the rain (Stanley Donen/Gene Kelly, 1952); Brigadoon (Vincente Minnelli, 1954); It's Always Fair Weather (Stanley Donen/Gene Kelly, 1955). Cyd Charisse starred in the last three alongside Kelly.

${ }^{\mathrm{v}}$ Coincidentally, Bardot began her contractions when watching a version of the opera of Carmen on television (Bardot, 1996: 343).

${ }^{\mathrm{vi}}$ A similar argument is advanced by Susan Weiner when talking about two films from this period, Adieu Philippine (Jacques Rozier, 1962) and Les Tricheurs (Marcel Carné, 1958): 'Each film (...) used the saturation of detail about the feminine to suggest the unrepresentability of the Algerian war' (Weiner, 2000: 169).

\section{Filmography}

Carmen di Trastevere/Carmen 63 (14 August 1962, Italy/France)

b\&w; length: 105 mins; production: Cocinor/Globe/Les Films Marceau/Produzione Gallone; director: Carmine Gallone; main actors: Giovanna Ralli (Carmen), Jacques Charrier (Antonio). 
Technicolor; length: 136 mins; production: Les Grandes Projections

Cinématographiques/Talma Films/Doper-filme/Joseph Kaufman; director: Terence Young; main actors: Zizi Jeanmaire (Carmen), Roland Petit (Don José).

\section{References}

Bardot, B. (1996), Initiales B.B.: mémoires, Paris: Livre de Poche.

Laubier, C. (1990), The Condition of Women in France 1945 to the Present: A

Documentary Anthology, London/New York: Routledge.

Bowen, C. (2002), 'The Choreography', website 'Zizi je t'aime', at http://www.pbs.org/wnet/gperf/zizi/html/work.html, accessed 21 June 2002.

Chapier, H. (1963), 'Carmen 63 de Carmine Gallone: un titre abusif au service de la médiocrité', Combat, 17 August 1963.

Choulant, D. (2009), Brigitte Bardot: le mythe éternel, Gémenos: Autre temps.

Crisp, C. (1993), The Classic French Cinema, 1930-1960, Bloomington/Indianapolis: Indiana University Press.

Davies, A., and Powrie, P. (2006), Carmen on Screen: An Annotated Filmography and Bibliography, Woodbridge: Boydell and Brewer (Tamesis, Research Bibliographies and Checklists: New Series 7).

Dine, P. (1994), Images of the Algerian War: French Fiction and Film, 1954-1992, Oxford: Clarendon Press.

France-Soir (1963), 'Carmen 63 (zéro)', France-Soir, 17 August 1963.

Frodon, J.-L. (1995), L’Âge moderne du cinéma français: de la Nouvelle Vague à nos jours, Paris: Flammarion.

Gili, J. and Tassone, A. (1995), Paris-Rome: cinquante ans de cinéma franco-italien, Paris: La Martinière. 
Hutcheon, L. (2006), A Theory of Adaptation, New York/Abingdon: Routledge.

'Intérim’ (1963), 'Carmen 63’, Le Figaro, 21 August 1963.

Lachize, S. (1963), “Carmen” fut-elle toujours trahie par le cinéma ? (A propos de Carmen 63, de Carmine Gallone)', L'Humanité, 17 August 1963.

Life (1949), 'Ballet: Two Imported Troupes Are New York’s Biggest Box-Office Hits', Life, 27 (20), 14 November, pp. 93-96.

Mackrell, J. (2002), 'All things to all men', The Guardian, 30 March, p.5.

McClary, S. (1992), Georges Bizet: 'Carmen', Cambridge: Cambridge University Press.

Monthly Film Bulletin (1961), 'Un, deux, trois, quatre! (Black Tights), France, 1960’, Monthly Film Bulletin, 28 (332): 125-26.

Paris-Presse (1962), 'Les Collants noirs', Paris-Presse, 19 June 1962.

Powrie, P., Babington, B., Davies, A., and Perriam, C. (2007), Carmen on Film: A Cultural History, Bloomington: Indiana University Press.

Soir de Bruxelles (1963), Untitled review, Le Soir de Bruxelles, 25 January 1963.

Télérama (1962), 'Les Collants noirs', Télérama, 3 July 1962.

Tremois, C. (1963), 'Carmen 63 (Carmen di Trastavere), Télérama, 1 September 1963.

Weiner, S. (1995), 'The consommatrice of the 1950s in Elsa Triolet's Roses à crédit', French Cultural Studies, 6 (17): 123-44.

Weiner, S. (2000), Enfants Terribles: Gender, Youth and the Mass Media in France 19451968, Baltimore: John Hopkins University Press. 